\title{
Implementation Knowledge Management in Management Thesis for Higher Education in Indonesia
}

\author{
Lila Setiyani ${ }^{1 *}$, Abdorrakhman Gintings ${ }^{2)}$, Abin Syamsudin ${ }^{3)}$, Daeng Arifin ${ }^{4)}$ \\ 1) STMIK ROSMA, 2,3,4) Universitas Islam Nusantara \\ 1) lila.setiyani@dosen.rosma.ac.id
}

DOI: https://doi.org/10.21107/rekayasa.v13i2.5909

\begin{abstract}
Management thesis in high education have some lackness in knowledge management. Every busines process that happen in management thesis don't have efective approach to integrate data workflow and to acuisition the knowledge. Therefore, knowledge management system for management thesis that suit with high education are needed. This paper gives suggestions about new architecture software that offer service for management thesis in high education to make business process more efective and efficien. Methodology that is used for development new software uses model process software development life cycle(SDLC) with web platform, that will increase collaboration in business process management thesis. The result of this implementation can increased efective and eficiency business process management thesis significantly.

Keywords: Thesis, High Education, Knowledge Management System, Software Development Life Cycle (SDLC)
\end{abstract}

\section{INTRODUCTION}

Thesis is the product of scientific work from students in bachelor program that is made base from the research with actual fenomena as academic requirement for high education in one semester (Aini Aliya Noor, 2011)]. In the process of thesis, students usually have supervisor . Furthermore the decision of graduation, depend on the examiner in the evaluation process(Sari, Windarto, Hartama, \& Solikhun, 2018). Product from thesis is scientifict work about new knowledge, high education should understand about the important of the managing knowledge , so that process business thesis can be produced the new knowledge that can solve actual problem and give implication for the skill of the reseacher. Therefore, high education need an efective and eficiency strategy to increase produce from business process thesis. In the study that is done by researcher in STMIK ROSMA, found some problems in business process thesis such as : planning phase, implemantation phase and evaluation phase. The first problem is planing phase. The students have problems in finding the idea to do the research. It makes the implication late graduation because of trouble in planning phase. The other trouble is finding process implementation thesis, Because information exchange that heppen in business process thesis

\section{Article History:}

Received: August, 30 th 2019; Accepted: May, $10^{\text {th }} 2020$

REKAYASA ISSN: 2502-5325 has been Accredited by Ristekdikti (Arjuna) Decree: No. 23/E/KPT/2019 August $8^{\text {th }}$, 2019 effective until 2023 isn't efective and eficien because some of them have done manually for instance mentoring and administration process. The last troubel is found in the evaluation process, the scoring is subjective.

Looking at the troubles, STMIK ROSMA need information system mangement thesis that manage administration and to support the creativity, sharing and repository knowledge . Although in the research, the researcher only use one population, but the result will suit with all population in high education. One of theories thatcan be used to manage knowledge in creating new knowledge which relevant with human resource need in the industrial revolution 4.0 (Wijaya, Sudjimat, \& Nyoto, 2016) is knowledge management that is aplication and inovation from knowledge that can increase the value of human(Hu, Hou, \& Chien, 2019).. In the knowledge management there are some process : create(Morente-Molinera, Pérez, Ureña, \& Herrera-Viedma, 2016) , save(Litvaj \& Stancekova, 2015), access(Oliveira, Curado, \& Henriques, 2019) and desimination(Chaplinskyy \& Subbotina, 2014 from intelectual organization(Antunes \& Pinheiro, 2019). To understand about knowledge management, we need to know about knowledge first. Base on Dvenport and Prusak, knowledge is combination from contextual information, frame of experience

\section{Cite this as:}

Setiyani, L., Gintings, A., Syamsudin, A., \& Arifin, D. (2020). Implementation Knowledge Management in Management Thesis for Higher Education in Indonesia. Rekayasa, 13(2), 144153. https://doi.org/10.21107/rekayasa.v13i2.5909 


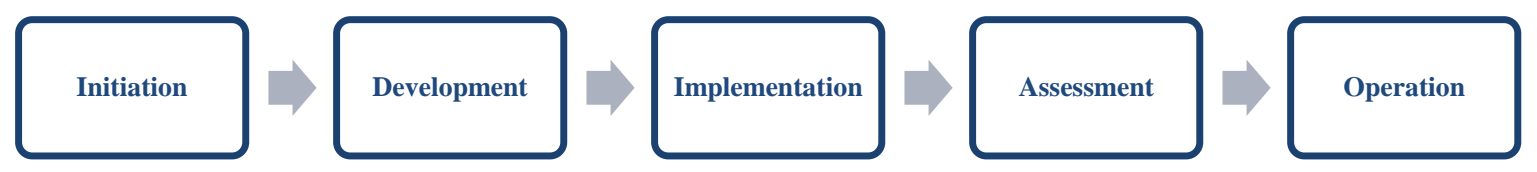

Figure 1. Stages of research

, experience from experts and value that produce inovation and pure experience. In spite of it, knowledge reference to organization culture, skill, reputation and intuition, code of theory that influence habit and mind of human(Abubakar, Elrehail, Alatailat, \& Elçi, 2019).. Nonaka has clasified about knowledge in two categories : tacit(Chergui, Zidat, \& Marir, 2018) and explicit(Barcelo-Valenzuela, Carrillo-Villafaña, Perez-Soltero, \& Sanchez-Schmitz, 2016) based on easy of coding or transfer in the visibility knowledge. Explisit knowledge is easy to transfer and coding in the pasive knowledge that is useless, so need to enable the aplication, and sharing, for that knowledge management take part in the process activation passive knowledge , so that knowledge will give advantage for organization(Abubakar et al., 2019).

Adoption of knowledge management in thesis business process can encourage the process of creation, sharing and storage of knowledge and the easy data exchange and information on the administration of the thesis so that the purpose of the thesis process can be achieved. Some researchers have conducted a lot of research using knowledge management approach, such as software development the HEARTEN KMS . It is a knowledge management system used to detect the health of patients. Nurses use HEARTEN KMS to observe the level of health of heart failure patients, which in the system there is the knowledge of cardiologist (Tripoliti et al., 2019). The organization of resource management has also adopted knowledge management for employee competency development (Lendzion, 2015). Knowledge management is also used by global logistics companies in the Middle East for sharing business and collaborative knowledge use (v. Alberti-Alhtaybat, Al-Htaybat, \& Hutaibat, 2019). Other research also reveals that knowledge management can improve the quality of existing doctors ' knowledge in New Zealand (Ali, Tretiakov, Whiddett, \& Hunter, 2017). The application of knowledge management in the field of education may be done, but integrated implementation as in the case studied by researchers did not exist. In the process of developing this thesis management system, researchers use a model of software development process namely software development life cycle (SDLC). This process Model is commonly called a waterfall that has five stages cycles consisting of initiation, development, implementation, assessment, and Operation (Broad, 2013). In addition to the waterfall, other process models included in the SDLC are prototypes (Holtkötter et al., 2018), Agile (Heeager \& Nielsen, 2018), Scrum (Lei, Ganjeizadeh, Jayachandran, \& Ozcan, 2017), etc.

\section{METHOD}

This research includes research and development $(R \& D)$ that seeks to develop a product (Haviz, 2013) i.e. software in the form of a thesis management system. The approach used in analyzing related value knowledge in the thesis business process is knowledge management as discussed in the introduction. As for developing such software products, researchers use the SDLC approach, because this approach has a framework that is easy to follow and way of software development to be created. Based on the merger of these two approaches, the stages of research at figure 1 .

1. Initiation

The initiation stage is the analysis of the system needs to define the features required by the thesis management system. The analysis process begins with arranging the schedule of activities, data collection matrix, data collection instruments. Based on schedules and matrices that have been compiled, researchers use data collection instruments as a basis to explore the information needed. The result of the data analysis, then processed to choose the system requirements. 
Table 1. Schedule of development of thesis management system

\begin{tabular}{|c|c|c|c|c|c|}
\hline Activity & M1 & M2 & M3 & M4 & M5 \\
\hline \multicolumn{6}{|c|}{ Preparation of matrix and data collection instruments } \\
\hline \multicolumn{6}{|l|}{ Data collection } \\
\hline \multicolumn{6}{|l|}{ Data processing } \\
\hline \multicolumn{6}{|l|}{ System Design } \\
\hline \multicolumn{6}{|c|}{ Construction Systems } \\
\hline \multicolumn{6}{|l|}{ Asessment system } \\
\hline Operation/Go Live & & & & & \\
\hline
\end{tabular}

2. Development

After the need of a thesis management system is chosen, the next step of the researcher makes the system design based on analysis results in the previous stage. This system design is described in the form of a flow process model document , called data flow diagram (Budiani, 2000)and a interaction system model with user (Fariza, Kom, \& Kom, 2016).

3. Implementation

When the design of the system was completed, the researcher translated the design into the script language base website that PHP programming (Walia \& Gill, 2014) with the MySql database (Sofwan, 2011). The selection of this programming language is based on the consideration of ease in accessing the system while MySql is considered by the free license platform.

4. Assessment

After the design was translated into programming language, then it was conducted the testing and assessment of the system in a unit and integrated (Woodside, Franks, \& Petriu, 1970). The results of these tests and assessment are used to base the operation of the system that the system is appropriated. If researcher found lack or deficiencies, the system will be returned to the process of analysis. The system testing process (Hartmann, Vieira, Foster, \& Ruder, 2005) use the Blackbox testing method (Nidhra, 2012), while the asessment process use the user acceptence test document (Davis \& Venkatesh, 2004).

5. Operation

Operation is a stage of system usage in real situation. At this stage, researchers conduct guidance to users, to anticipate the problems or difficulties in the use of the system.

\section{RESULT}

Based on the knowledge management and SDLC approach used in the development of the thesis management system, the following are the research results:

1. Initiation

The initiation stage resulted in a schedule and a list of activities undertaken in the process of developing the system. Table 1 is the schedule of system development activities:

The first activity is the preparation of data collection matrix that aims to clarify the data or information to be excavated. Here is a form of data collection matrix:

Table 2. Data collection Matrik

\begin{tabular}{|c|c|c|}
\hline $\begin{array}{l}\text { Data/Informat } \\
\text { ion excavated }\end{array}$ & $\begin{array}{l}\text { Data } \\
\text { Source }\end{array}$ & $\begin{array}{l}\text { Data } \\
\text { Collection } \\
\text { Techniques }\end{array}$ \\
\hline $\begin{array}{l}\text { Thesis Business } \\
\text { Process } \\
\text { Planning }\end{array}$ & $\begin{array}{l}\text { Coodinat } \\
\text { or thesis, } \\
\text { student, } \\
\text { industry }\end{array}$ & $\begin{array}{l}\text { Interviews } \\
\text { and } \\
\text { Documentati } \\
\text { on Studies }\end{array}$ \\
\hline $\begin{array}{l}\text { Implementation } \\
\text { of thesis } \\
\text { Business } \\
\text { process }\end{array}$ & $\begin{array}{l}\text { Coodinat } \\
\text { or thesis, } \\
\text { student, } \\
\text { industry }\end{array}$ & $\begin{array}{l}\text { Interviews } \\
\text { and } \\
\text { Documentati } \\
\text { on Studies }\end{array}$ \\
\hline $\begin{array}{l}\text { Thesis Business } \\
\text { Process } \\
\text { Evaluation }\end{array}$ & $\begin{array}{l}\text { Coodinat } \\
\text { or thesis, } \\
\text { student, } \\
\text { industry }\end{array}$ & $\begin{array}{l}\text { Interviews } \\
\text { and } \\
\text { Documentati } \\
\text { on Studies } \\
\end{array}$ \\
\hline
\end{tabular}

From the matrix of the data collection, researchers compiled a research instrument such the interview script and documentation checklist. Based on the instruments that have been created, 
Tabel 3. Knowledge mapping

\begin{tabular}{|c|c|c|c|c|}
\hline $\begin{array}{l}\text { Business } \\
\text { Process }\end{array}$ & $\begin{array}{c}\text { Knowledge } \\
\text { Form }\end{array}$ & Knowledge & $\begin{array}{l}\text { Knowledge } \\
\text { Resources }\end{array}$ & $\begin{array}{c}\text { Domain Knowledge } \\
\text { Management }\end{array}$ \\
\hline \multirow[t]{7}{*}{ Planning } & $\begin{array}{l}\text { Tacit } \\
\text { knowledge }\end{array}$ & $\begin{array}{l}\text { The knowledge of } \\
\text { lecture and industry } \\
\text { haven't been explicitly } \\
\text { compiled as a student } \\
\text { literature material to } \\
\text { make a thesis } \\
\text { proposal }\end{array}$ & Lecturer, Industry & $\begin{array}{l}\text { Knowledge repository and } \\
\text { knowledge culture sharing }\end{array}$ \\
\hline & $\begin{array}{l}\text { Explicit } \\
\text { knowledge }\end{array}$ & $\begin{array}{l}\text { Industry Database } \\
\text { that has cooperated } \\
\text { with Major }\end{array}$ & Head of IT Major & $\begin{array}{l}\text { Knowledge repository and } \\
\text { knowledge culture sharing }\end{array}$ \\
\hline & $\begin{array}{l}\text { Explicit } \\
\text { knowledge }\end{array}$ & $\begin{array}{l}\text { Registration form for } \\
\text { proposal asessment, } \\
\text { draft of thesis }\end{array}$ & $\begin{array}{l}\text { Academic } \\
\text { Administration or } \\
\text { thesis Coordinator }\end{array}$ & Knowledge repository \\
\hline & $\begin{array}{l}\text { Tacit } \\
\text { knowledge }\end{array}$ & $\begin{array}{l}\text { Database of the } \\
\text { Lecturer Expertise } \\
\text { field }\end{array}$ & Lecturer & Knowledge repository \\
\hline & $\begin{array}{l}\text { Explicit } \\
\text { knowledge }\end{array}$ & $\begin{array}{l}\text { Asessment thesis } \\
\text { schedule and list of } \\
\text { assesors. }\end{array}$ & $\begin{array}{l}\text { Academic } \\
\text { Administration or } \\
\text { thesis Coordinator }\end{array}$ & $\begin{array}{l}\text { Knowledge repository and } \\
\text { knowledge culture sharing }\end{array}$ \\
\hline & $\begin{array}{l}\text { Explicit } \\
\text { knowledge }\end{array}$ & $\begin{array}{l}\text { Review proposal, } \\
\text { proposal form scoring }\end{array}$ & $\begin{array}{l}\text { Academic } \\
\text { Administration or } \\
\text { thesis coordinator, } \\
\text { student, lecturer }\end{array}$ & $\begin{array}{l}\text { Knowledge repository and } \\
\text { knowledge culture sharing }\end{array}$ \\
\hline & $\begin{array}{l}\text { Explicit } \\
\text { knowledge }\end{array}$ & $\begin{array}{l}\text { Mentoring Guide } \\
\text { Licence }\end{array}$ & Thesis Coordinator & $\begin{array}{l}\text { Knowledge repository and } \\
\text { knowledge culture sharing }\end{array}$ \\
\hline \multirow[t]{6}{*}{$\begin{array}{l}\text { Implemen- } \\
\text { tation }\end{array}$} & $\begin{array}{l}\text { Tacit } \\
\text { knowledge }\end{array}$ & $\begin{array}{l}\text { Review and approval } \\
\text { in thesis mentoring }\end{array}$ & Lecturer & $\begin{array}{l}\text { Knowledge repository and } \\
\text { knowledge culture sharing }\end{array}$ \\
\hline & Explicit & Seminar Registration & Academic & Knowledge repository \\
\hline & knowledge & Form, seminar draft & $\begin{array}{l}\text { Administration or } \\
\text { thesis Coordinator }\end{array}$ & \\
\hline & $\begin{array}{l}\text { Tacit } \\
\text { knowledge }\end{array}$ & $\begin{array}{l}\text { Database of the } \\
\text { Lecturer Expertise } \\
\text { field }\end{array}$ & Lecturer & Knowledge repository \\
\hline & $\begin{array}{l}\text { Explicit } \\
\text { knowledge }\end{array}$ & $\begin{array}{l}\text { Review seminar and } \\
\text { seminar form scoring }\end{array}$ & $\begin{array}{l}\text { Academic } \\
\text { Administration or } \\
\text { thesis coordinator, } \\
\text { student, lecturer }\end{array}$ & $\begin{array}{l}\text { Knowledge repository and } \\
\text { knowledge culture sharing }\end{array}$ \\
\hline & $\begin{array}{l}\text { Explicit } \\
\text { knowledge }\end{array}$ & $\begin{array}{l}\text { Review thesis } \\
\text { progress }\end{array}$ & Students & Knowledge repository \\
\hline \multirow[t]{5}{*}{ Evaluation } & $\begin{array}{l}\text { Explicit } \\
\text { knowledge }\end{array}$ & $\begin{array}{l}\text { Registration form, } \\
\text { draft thesis }\end{array}$ & $\begin{array}{l}\text { Academic } \\
\text { Administration or } \\
\text { thesis Coordinator }\end{array}$ & $\begin{array}{l}\text { Knowledge repository and } \\
\text { knowledge culture sharing }\end{array}$ \\
\hline & $\begin{array}{l}\text { Tacit } \\
\text { knowledge }\end{array}$ & $\begin{array}{l}\text { Database of the } \\
\text { Lecturer Expertise } \\
\text { field }\end{array}$ & Lecturer & Knowledge repository \\
\hline & $\begin{array}{l}\text { Explicit } \\
\text { knowledge }\end{array}$ & $\begin{array}{l}\text { Review thesis } \\
\text { asessment, scoring } \\
\text { thesis asessment form }\end{array}$ & $\begin{array}{l}\text { Academic } \\
\text { Administration or } \\
\text { thesis coordinator, } \\
\text { student, lecturer }\end{array}$ & $\begin{array}{l}\text { Knowledge repository and } \\
\text { knowledge culture sharing }\end{array}$ \\
\hline & $\begin{array}{l}\text { Explicit } \\
\text { knowledge }\end{array}$ & $\begin{array}{l}\text { Thesis submitted } \\
\text { form }\end{array}$ & Library Coordinator & $\begin{array}{l}\text { Knowledge repository and } \\
\text { knowledge culture sharing }\end{array}$ \\
\hline & $\begin{array}{l}\text { Explicit } \\
\text { knowledge }\end{array}$ & Publication Journal & LPPM & $\begin{array}{l}\text { Knowledge repository and } \\
\text { knowledge culture sharing }\end{array}$ \\
\hline
\end{tabular}


The result of it, will be analyzed to map the sources of knowledge in the business process of the thesis called Knowledge Mapping (Wexler, 2001). Table 3 is the knowledge mapping thesis:

Beside analysis of knowledge mapping, researchers analyzed thesis business process. The results of the business process analysis are obtained three processes : planning, implementation and evaluation of the thesis. After the results of business process analysis and knowledge mapping are obtained, then researchers identify the system requirement. Here is the result of the identification of the weaknesses in the existing thesis business process:

a. There are no media collaboration between lecturers, students, and industry.

b. There are no media that can help students to meet industry for the process of licensing research.

c. There are no information system of thesis administration

d. There are no media that facilitates the industry to evaluate products or research reports from the students.

e. Students and lecture aren't able to find complete online guidance with its storage(repository).

f. The media digital that facilitate the repository report and research product isn't found.

g. Students have problem in submiting proposal that make them graduate lately. The stundents feel dificult to find the idea because there aren't brainstroming support media.

h. There are student who get trouble in the process of thesis because uneffective and unefficiency mentoring process.

Based on the problems identification of the thesis business process above, it can be set features that must be in the thesis management system are : a. Feature Focus group discussion (FGD) that can facilitate brainstroming research topics. In this FGD is meet up between lecturers, alumni, industry, management and students to be able to share the knowledge. Lecturers can guide directly students in the forum as well as industry and alumni who can emphasize the needs in the industry or business world.

b. Online Registration feature can facilitate students in the licensing of research place. Student can directly submit on the desired industry options. Industry listed on this system is an industry that has been cooperating with IT Major.

c. Thesis administration features that facilitate the administrative process of proposal registration, guidance matriculation, exam registration and assessment (by Examiner, mentor and industry ). In this feature, coordinators can supervise the progress of student research, which can accelerate decision-making by the thesis coordinator.

d. The thesis supervision feature that facilitates the review process of online report documents and online approval.

e. The Knowledge repository feature, computerized archiving of student researchers that can be used as a referance and material research ideas or research development.

f. Lecturer database features, which assist the thesis Coordinator in the matriculation of the tutors and examiner.

2. Development

Based on the features that have been set, at this stage researchers create a design of a thesis management system with the following details at figure 2, figure 3 and figure 4 . 


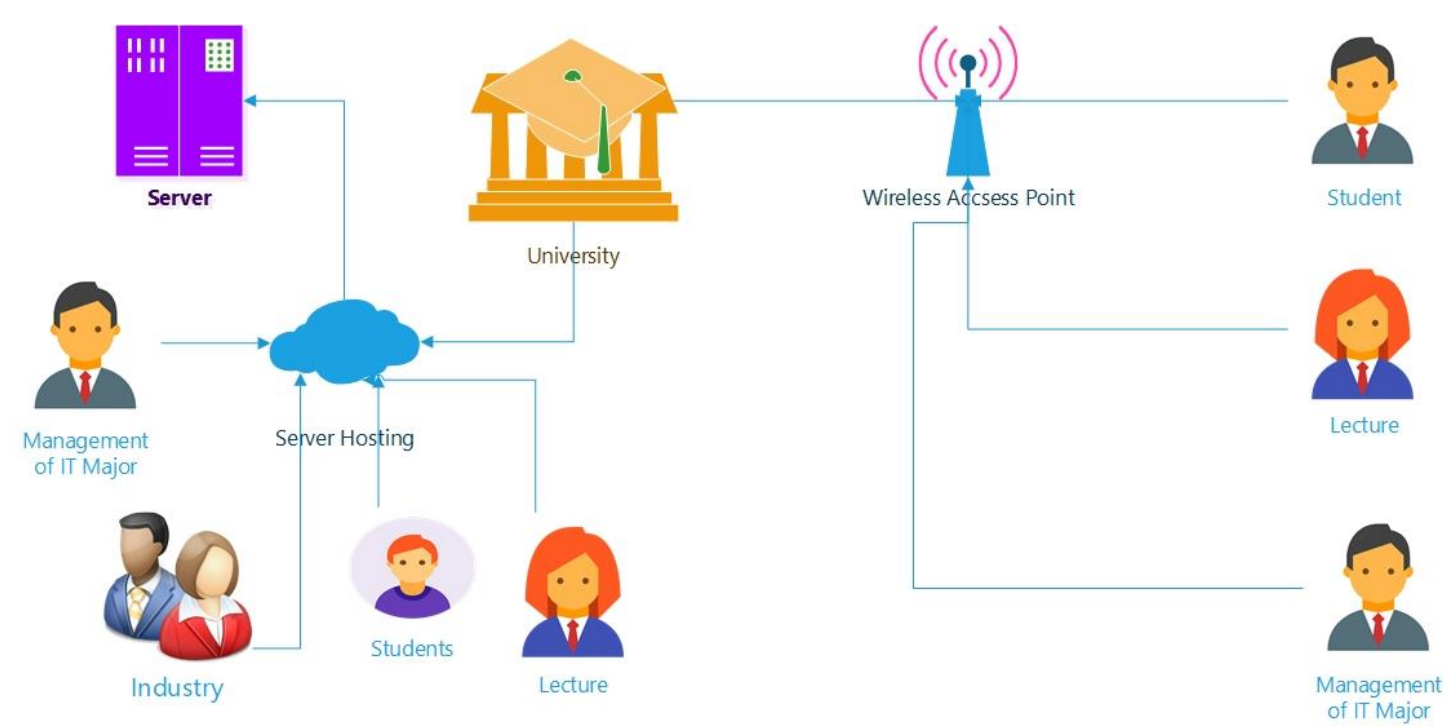

Figure 2. Design network architecture of thesis management system.

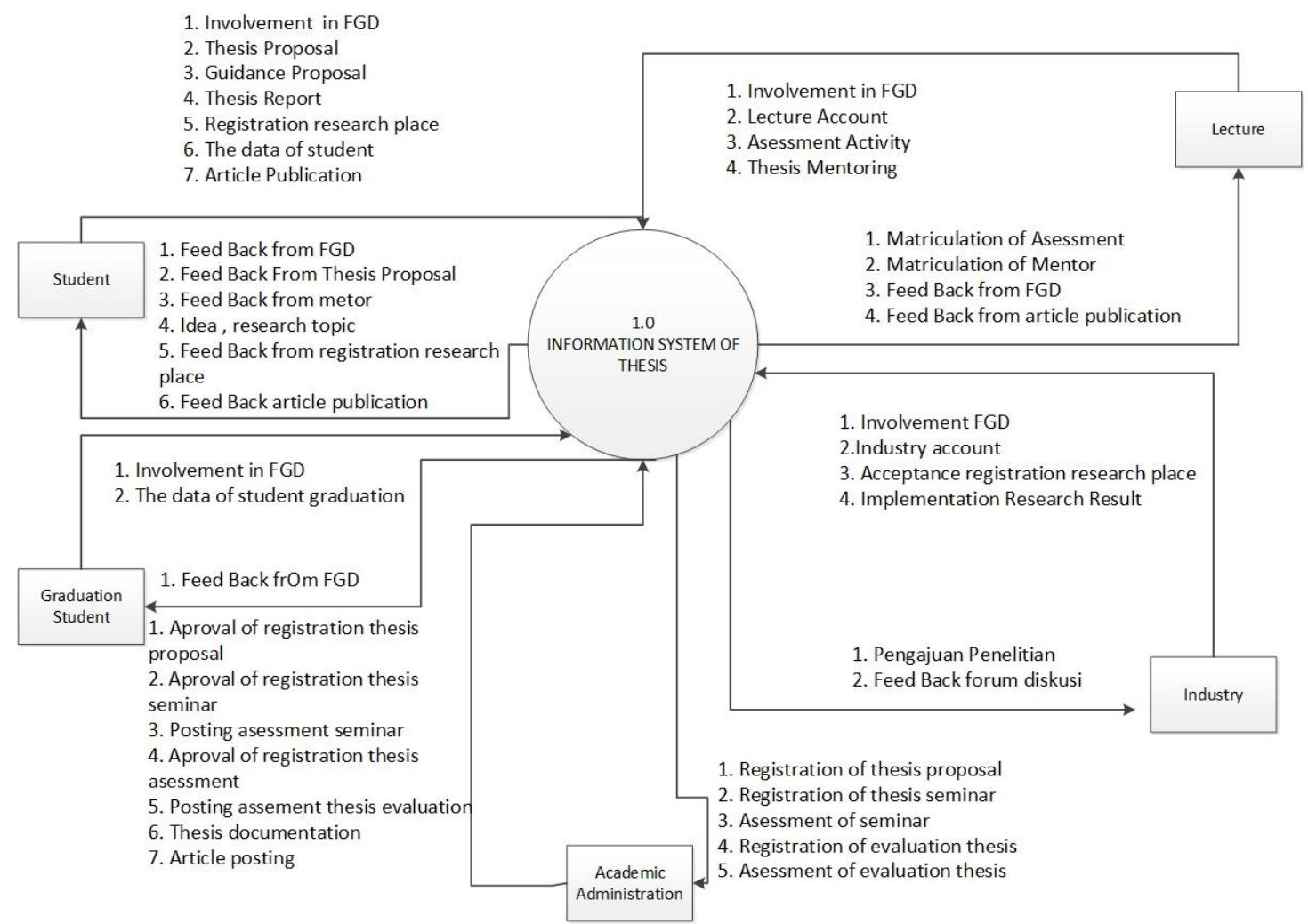

Figure 3. Document design process flow documents thesis management system.

Design of the computer network Aristektur in Picture 1 illustrate how the Thesis management system is accessed in the computer network. In Figure 2 describes the flow of documents that enter the system and that are out of the system. Whereas picture 3 describes the menus that are accessible by the user. In addition to the three designs above, researchers also created database design and draft input and output thesis management system.

3. Implementasi.

Based on the design of the system that has been created, the translation of the design into Web-based programming language PHP with a database using MySQL. When the system has finished in the translate 
150 | Setiyani, L. et.al. Implementation Knowledge Management in Management Thesis...

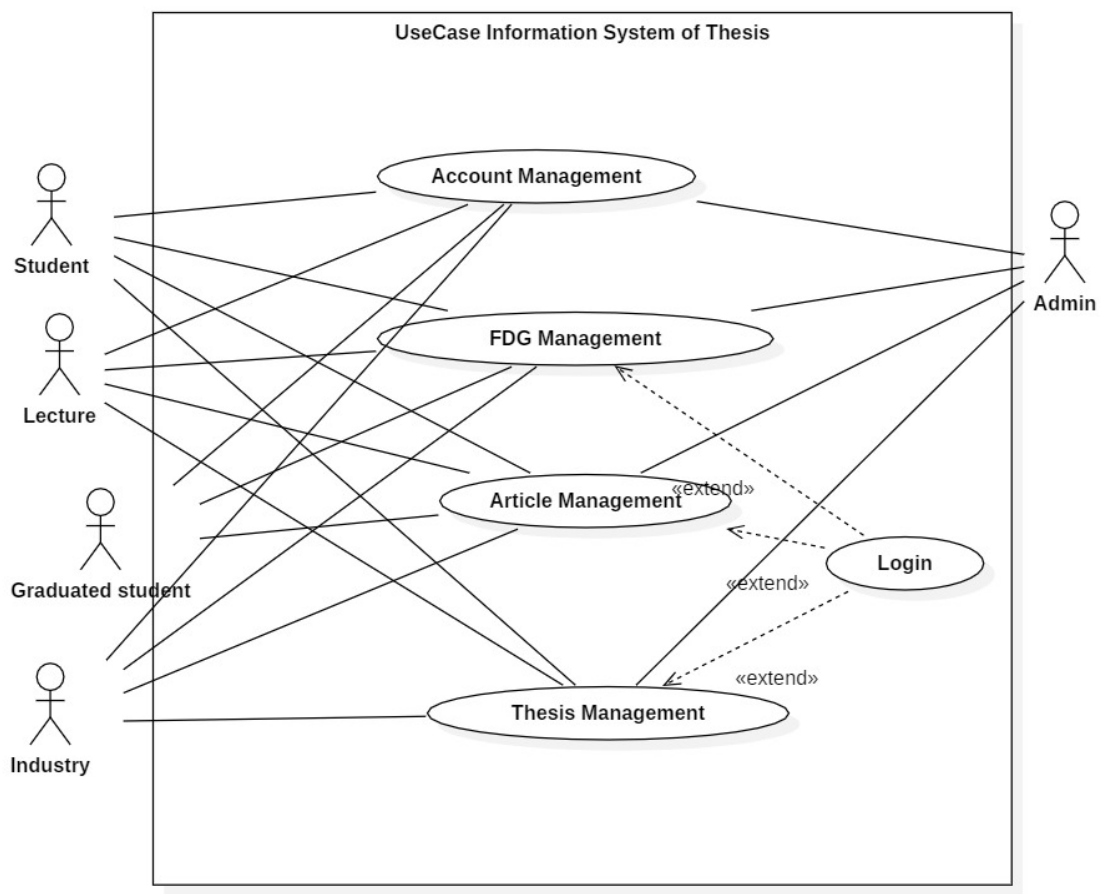

Figure 4. User interaction design with thesis management system.

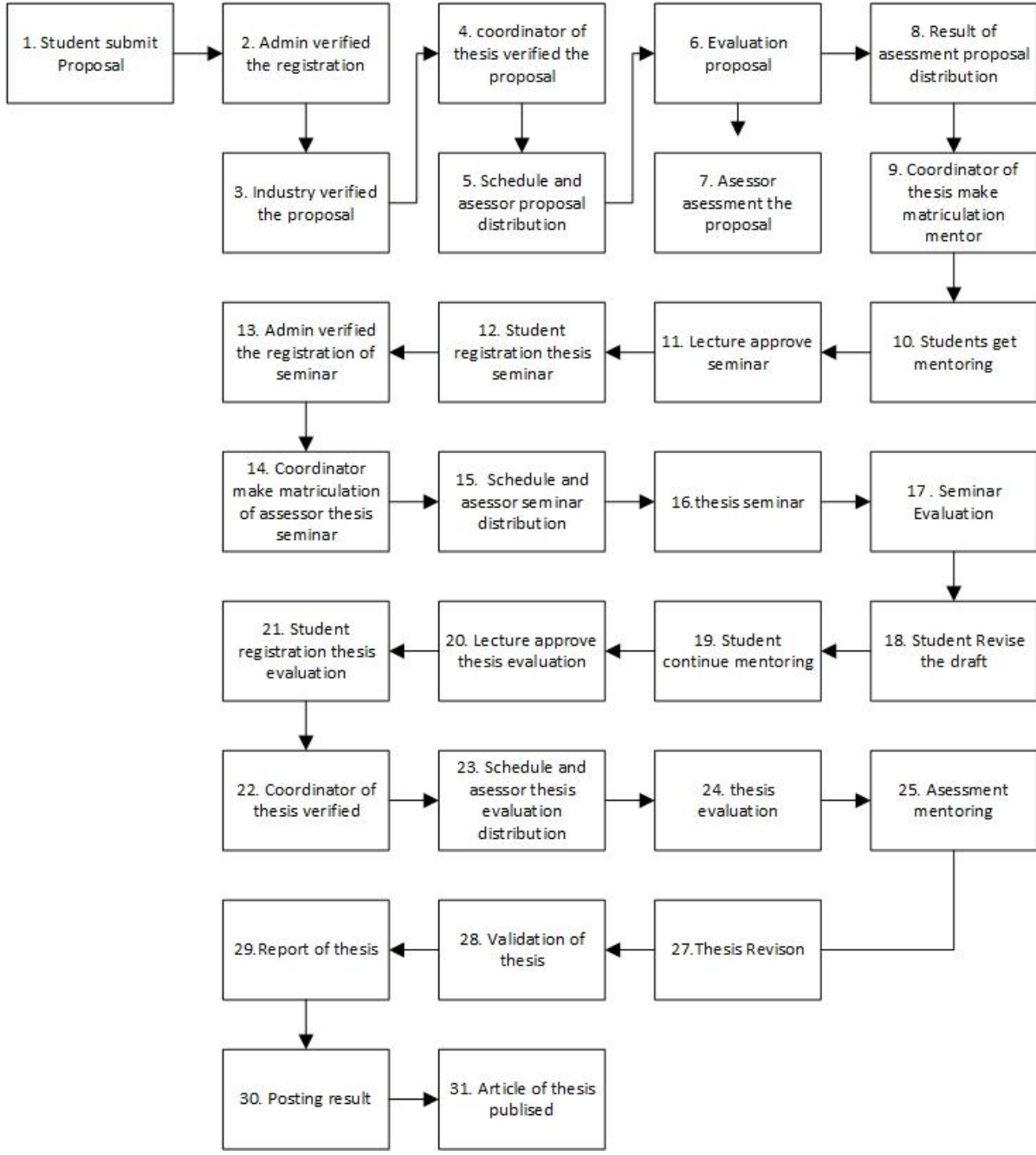

Figure 5. Overview of integrated system testing flow. 
are integrated using the Blackbox testing method. Testing the unit is done on every feature of the system, while integrated testing is conducted by following the existing business process. Here is an overview of integrated system testing (figure 5.)

4. Assesment

The asessment process is done by compiling the document user acceptance Test (UAT), providing training on the use of the system and spread the document to all users at each point of the integrated testing. This technique aims to excavate the benefits of the system or to eliminate system defects. The results of such documents are considered, whether the system is ready to be operated or required additional features.

5. Operation

At this stage, the thesis management system is properly operated to manage the thesis business process. Activities conducted by researchers in this process are accompanying the user in the operation process, this is done to help the user if experiencing difficulties in the process of system use.

\section{CONCLUSSION}

Based on the results of the studies above, it can be concluded that knowledge management can be a tool that can be used to improve the effectiveness and efficiency of the thesis business process. whereas the SDLC approach can be used as a reference in developing an information system. This article can be a guide for organizations that will build information systems using the knowledge management and SDLC approaches. With the successful application of knowledge management in thesis business process, the upcoming research may be able to apply to other business processes such as elearning, research lab, etc.

\section{REFFERENCE}

Abubakar, A. M., Elrehail, H., Alatailat, M. A., \& Elçi, A. (2019). Knowledge management, decision-making style and organizational performance. Journal of Innovation \& Knowledge, 4(2), 104-114. https://doi.org/10.1016/j.jik.2017.07.003

Aini Aliya Noor, M. I. H. (2011). Hubungan antara Kontrol Diri dengan Prokrastinasi dalam Menyelesaikan Skripsi pada Mahasiswa Universitas Muria Kudus. Jurnal Psikologi: PITUTUR, 1(2), 65-71.

Ali, N., Tretiakov, A., Whiddett, D., \& Hunter, I. (2017). Knowledge management systems success in healthcare: Leadership matters. International Journal of Medical Informatics, 97, 331-340. https://doi.org/10.1016/j.jimedinf.2016. 11.004

Antunes, H. de J. G., \& Pinheiro, P. G. (2019). Linking knowledge management, organizational learning and memory. Journal of Innovation \& Knowledge. https://doi.org/10.1016/j.jik.2019.04.002

Barcelo-Valenzuela, M., Carrillo-Villafaña, P. S., Perez-Soltero, A., \& Sanchez-Schmitz, G. (2016). A framework to acquire explicit knowledge stored on different versions of software. Information and Software Technology, 70, 40-48. https://doi.org/10.1016/j.infsof.2015.09. 007

Broad, J. (2013). System Development Life Cycle (SDLC). Risk Management Framework, 39-45. https://doi.org/10.1016/b978-159749-995-8.00005-3

Budiani, N. (2000). DATA FLOW DIAGRAM: sebagai alat bantu desain sistem. Bagian Pemeliharaan Sistem Aplikasi Biro Pengembangan Aplikasi Komputer, (April). Retrieved from http://pranata.kemenkeu.go.id/website/ 3/DFD sebagai alat bantu design system.pdf

Chaplinskyy, Y., \& Subbotina, O. (2014). Ontology-driven Advice and Decisionmaking within Knowledge Dissemination for Extension. Procedia Technology, 8(Haicta), 453-458. https://doi.org/10.1016/j.protcy.2013.11. 058

Chergui, W., Zidat, S., \& Marir, F. (2018). An approach to the acquisition of tacit knowledge based on an ontological model. Journal of King Saud University Computer and Information Sciences. 
https://doi.org/10.1016/j.jksuci.2018.09. 012

Davis, F. D., \& Venkatesh, V. (2004). Toward preprototype user acceptance testing of new information systems. IEEE Transactions on Engineering Management, 51(1), 31-46. https://doi.org/10.1109/TEM.2003.8224 68 T4 - Implications for software project management M4 - Citavi

Fariza, A., Kom, S., \& Kom, M. (2016). OBJECT MODELING TECHNIQUE. 1-11.

Hartmann, J., Vieira, M., Foster, H., \& Ruder, A. (2005). A UML-based approach to system testing. Innovations in Systems and Software Engineering, 1(1), 12-24. https://doi.org/10.1007/s11334-0050006-0

Haviz, M. (2013). Research and Development; Penelitian Di Bidang Kependidikan Yang Inovatif, Produktif Dan Bermakna. Ta'dib, 16(1).

Heeager, L. T., \& Nielsen, P. A. (2018). A conceptual model of agile software development in a safety-critical context: A systematic literature review. Information and Software Technology, 103, 22-39. https://doi.org/10.1016/j.infsof.2018.06. 004

Holtkötter, J., Michael, J., Henke, C., Trächtler, A., Bockholt, M., Möhlenkamp, A., \& Katter, M. (2018). Rapid-Control-Prototyping as part of Model-Based Development of Heat Pump Dryers. Procedia Manufacturing, 24, 235-242. https://doi.org/10.1016/j.promfg.2018.0 6.033

Hu, Y. F., Hou, J. L., \& Chien, C. F. (2019). A UNISON framework for knowledge management of university-industry collaboration and an illustration. Computers and Industrial Engineering, 129, 31-43. https://doi.org/10.1016/j.cie.2018.12.07 2

Lei, H., Ganjeizadeh, F., Jayachandran, P. K., \& Ozcan, P. (2017). A statistical analysis of the effects of Scrum and Kanban on software development projects. Robotics and Computer-Integrated Manufacturing, 43 ,

59-67. https://doi.org/10.1016/j.rcim.2015.12.0 01

Lendzion, J. P. (2015). Human Resources Management in the System of Organizational Knowledge Management. Procedia Manufacturing, 3(Ahfe), 674-680. https://doi.org/10.1016/j.promfg.2015.0 7.303

Litvaj, I., \& Stancekova, D. (2015). Knowledge Management Embedment in Company, Knowledge Repositories, Knowledge Management Significance and Usage in Company. Procedia Economics and Finance, 23(October 2014), 833-838. https://doi.org/10.1016/s22125671(15)00549-3

Morente-Molinera, J. A., Pérez, I. J., Ureña, M. R., \& Herrera-Viedma, E. (2016). Creating knowledge databases for storing and sharing people knowledge automatically using group decision making and fuzzy ontologies. Information Sciences, 328, 418-434. https://doi.org/10.1016/j.ins.2015.08.05 1

Nidhra, S. (2012). Black Box and White Box Testing Techniques - A Literature Review. International Journal of Embedded Systems and Applications, 2(2), 29-50. https://doi.org/10.5121/ijesa.2012.2204

Oliveira, M., Curado, C., \& Henriques, P. L. (2019). Knowledge sharing among scientists: A causal configuration analysis. Journal of Business Research, 101(June), 777-782. https://doi.org/10.1016/j.jbusres.2018.1 2.044

Sari, D. R., Windarto, A. P., Hartama, D., \& Solikhun, S. (2018). Sistem Pendukung Keputusan untuk Rekomendasi Kelulusan Sidang Skripsi Menggunakan Metode AHP-TOPSIS. Jurnal Teknologi Dan Sistem Komputer, 6(1), 1. https://doi.org/10.14710/jtsiskom.6.1.20 18.1-6

Sofwan, A. (2011). Belajar Mysql dengan Phpmyadmin Pendahuluan. Modul Kuliah Graphical User Interface I (GUI) Di Perguruan Tinggi Raharja, 1-29.

Teknik, F., \& Indonesia, U. (2006). Pedoman penulisan skripsi 2006. 1-44. 
Tripoliti, E. E., Karanasiou, G. S., Kalatzis, F. G., Bechlioulis, A., Goletsis, Y., Naka, K., \& Fotiadis, D. I. (2019). HEARTEN KMS - A knowledge management system targeting the management of patients with heart failure. Journal of Biomedical Informatics, 94, 103203. https://doi.org/10.1016/j.jbi.2019.10320 3

v. Alberti-Alhtaybat, L., Al-Htaybat, K., \& Hutaibat, K. (2019). A knowledge management and sharing business model for dealing with disruption: The case of Aramex. Journal of Business Research, 94(August), 400-407. https://doi.org/10.1016/j.jbusres.2017.1 1.037

Walia, S., \& Gill, S. (2014). A Framework for Web Based Student Record Management System using PHP. International Journal of Computer Science and Mobile Computing ISSN 2320-088X, 3(8), 24-33.
Wexler, M. N. (2001). The who, what and why of knowledge mapping. Journal of Knowledge Management, 5(3), 249-264. https://doi.org/10.1108/EUM000000000 5868

Wijaya, E. Y., Sudjimat, D. A., \& Nyoto, A. (2016). Transformasi Pendidikan Abad 21 Sebagai Tuntutan. Jurnal Pendidikan, 1, 263-278. Retrieved from http://repository.unikama.ac.id/840/32/ 263-278 TRANSFORMASI PENDIDIKAN ABAD 21 SEBAGAI TUNTUTAN PENGEMBANGAN SUMBER DAYA MANUSIA DI ERA GLOBAL.pdf. diakses pada; hari/tgl; sabtu, 3 November 2018. jam; 00:26, wib.

Woodside, M., Franks, G., \& Petriu, D. C. (1970). The Future of Software Performance Engineering The Future of Software Performance Engineering. Knowledge Creation Diffusion Utilization. 